\title{
Fat and fatty acid composition of cooked meat from UK retail chickens labelled as from organic and non-organic production systems
}

Article

Accepted Version

Dalziel, C. J., Kliem, K. E. and Givens, D. I. (2015) Fat and fatty acid composition of cooked meat from UK retail chickens labelled as from organic and non-organic production systems. Food Chemistry, 179. pp. 103-108. ISSN 0308-8146 doi: https://doi.org/10.1016/j.foodchem.2015.01.118 Available at https://centaur.reading.ac.uk/39249/

It is advisable to refer to the publisher's version if you intend to cite from the work. See Guidance on citing.

Published version at: http://www.sciencedirect.com/science/article/pii/S0308814615001338

To link to this article DOI: http://dx.doi.org/10.1016/j.foodchem.2015.01.118

Publisher: Elsevier

All outputs in CentAUR are protected by Intellectual Property Rights law, including copyright law. Copyright and IPR is retained by the creators or other copyright holders. Terms and conditions for use of this material are defined in the End User Agreement. 


\section{CentAUR}

Central Archive at the University of Reading

Reading's research outputs online 
2 Fat and fatty acid composition of cooked meat from UK retail chickens labelled as from organic and non-organic production systems

4

5 Courtney J. Dalziel, Kirsty E. Kliem and D. Ian Givens*

6

7 Food Production and Quality Division, School of Agriculture, Policy and Development, University 8 of Reading, Reading RG6 6AR, United Kingdom

9

10 Running title: Fatty acids in organic vs. normal chicken meat

11

12 Keywords: chicken meat: fat: fatty acids: conventional vs. organic

13

\footnotetext{
*Corresponding author, Tel: +44 118378 8491; email: d.i.givens@reading.ac.uk
} 


\section{Abstract}

This study compared fat and fatty acids in cooked retail chicken meat from conventional and organic systems. Fat contents were 1.7, 5.2, 7.1 and $12.9 \mathrm{~g} / 100 \mathrm{~g}$ cooked weight in skinless breast, breast with skin, skinless leg and leg with skin respectively, with organic meat containing less fat overall $(P<0.01)$. Meat was rich in cis-monounsaturated fatty acids although organic contained less than conventional meat (1850 vs. $2538 \mathrm{mg} / 100 \mathrm{~g} ; P<0.001)$. Organic meat was also lower $(P<0.001)$ in $18: 3 \mathrm{n}-3(115$ vs. $180 \mathrm{mg} / 100 \mathrm{~g})$ and whilst it contained more $(P<0.001)$ docosahexaenoic acid (30.9 vs. $13.7 \mathrm{mg} / 100 \mathrm{~g}$ ) this was due to the large effect of one supermarket. This system by supermarket interaction suggests that poultry meat labelled as organic is not a guarantee of higher long chain n-3 fatty acids. Overall there were few major differences in fatty acid contents/profiles between organic and conventional meat that were consistent across all supermarkets.

\section{Keywords: chicken meat; fat; fatty acids; conventional vs. organic}

\section{Introduction}

Consumption of poultry meat in the UK has increased very considerably over the last 60 years from about $15 \mathrm{~g} /$ person/week in 1950 (MAFF, 2001) to around $469 \mathrm{~g} /$ person/week including poultry meat dishes recently (Bates et al., 2014). There have been concerns that modern chicken meat contains considerably more fat than was the case some years ago (Wang, Lehane, Ghebremeskel and Crawford, 2009), although there are few truly comparative studies to support this and the recent National Diet and Nutrition Survey (Bates et al., 2014) confirmed that chicken and turkey meat and meat products contribute only $6-7 \%$ of dietary fat intake. Poultry meat does however have a very 
0

variable fat content depending on which part of the bird's body the meat is derived and whether skin is included (Givens, Gibbs, Rymer and Brown, 2011).

There has been interest in the role of poultry meat as a dietary source of long chain n-3 polyunsaturated fatty acids (PUFA), mainly eicosapentaenoic acid (EPA, 20:3 n-3) and docosahexaenoic acid (DHA, 22:6 n-3). Intake of these fatty acids is below the recommended value of $450 \mathrm{mg} / \mathrm{d}$ (SACN/COT, 2004) in large parts of the UK population, primarily due to a low intake of oily fish (Givens and Gibbs, 2006). Givens and Gibbs (2006, 2008) estimated that the then current consumption of chicken meat would provide about $27 \mathrm{mg}$ of EPA + DHA per day. This was based on average EPA (15 mg/100g) and DHA (35 mg/100g) concentrations in meat reported in research papers dating from 1990s to 2000 which may not have been representative of retail meat, and a more recent study has reported much lower concentrations in cooked retail chicken meat (Givens et al., 2011). Givens et al. (2011) also found that meat from free range birds had significantly lower concentrations of EPA and total n-3 fatty acids than meat from conventionally reared birds, suggesting that perhaps differences in management practices between the two systems, such as diet composition, may have an effect. Demand for organic poultry, another type of production system, has increased across all social groups in the UK since 1995 with the exception of 2007-2008 owing to the recession (Dangour, Dodhia, Hayter, Allen, Lock and Uauy, 2009; Soil Association, 2010). Organic production systems need to conform to certain regulations (European Commission, 2008) which place restrictions on the ingredients which can be included in the birds' diet, which may in turn influence the fatty acid composition of the meat. The review of Minihane, Givens and Gibbs (2008) concluded that there were few truly comparative data on the fat and fatty acid content of retail chicken meat from organic versus conventional production systems. Moreover, the available studies were not representative of meat sold in the UK 
and most studies analysed fresh rather than cooked meat. The main objective of the current study was to compare the fat and fatty acid content of cooked meat from retail chickens labelled as being derived from conventional or organic production systems.

\section{Materials and methods}

\subsection{Chickens and sampling}

Two low-cost, fresh, chilled non-organic (assumed to be intensive) reared, dressed broiler chickens and two fresh, dressed, chilled birds labelled as from organic production of near identical weight (1.5-1.6 kg) were purchased from each of three leading supermarkets in February 2011 (Table 1). All packaging and any giblets and loose internal fat were removed and all 12 birds were weighed. Without adding anything, each bird was placed in a roasting bag (Bacofoil Flavour Seal Roasting Bags; Wrap Film Systems Ltd, Telford, Shropshire, UK) and cooked breast upwards in a preheated oven set at $180^{\circ} \mathrm{C}$ for 20 minutes per $500 \mathrm{~g}$ followed by an additional 20 minutes according to the Roasting Bag instructions. After cooking, birds were removed from the bags and any juices were allowed to drain away. After cooling, breast meat and legs were dissected from the body. One breast and one leg had the skin removed. All edible meat (i.e. excluding connective tissue) from thigh and lower leg was removed from both legs. This process thus provided a total of 48 samples; six skinless breasts, six breasts with skin, six sets of skinless leg meat and six sets of leg meat with skin for both conventional and organically produced birds. Prepared meat samples were stored in labelled, sealed polythene food bags at $1-2^{\circ} \mathrm{C}$ for a short period following which each sample was homogenised twice in a bench-top meat mincer (Tre Spade Type 12EL/160 ELG, F.A.C.E.M. SpA, Turin, Italy) and then stored at $-20^{\circ} \mathrm{C}$ prior to analysis. During storage one sample (organic breast meat with skin) was slightly damaged and was not analysed. 
For total fat and fatty acid analysis, thawed meat samples were freeze-dried over a period of three days, followed by grinding to a fine powder using a pestle and mortar. The powdered samples were stored in labelled, sealable polythene food bags at $-20^{\circ} \mathrm{C}$ until analysed. Total fat was quantified by extraction of the oil from the freeze-dried material (4.0-4.6 g) with light petroleum ether (boiling range $40-60^{\circ} \mathrm{C}$ ) using a 'Soxflo' apparatus (Brown and Mueller-Harvey, 1999) at room temperature.

97 
minute to $240^{\circ} \mathrm{C}$ and held for 8 minutes. FAME were identified using retention times cross referenced against external mixed standards (GLC463 Nu-Chek-Prep Inc, Elysian, MN and O4754, O9881, E4762, V1381, Sigma-Aldrich Company Ltd., Dorset, UK). FAME were then quantified using the peak area from the known concentration of heneicosanoic acid FAME added to the process at the beginning of the methylation stage.

\subsection{Statistical analysis}

The effect of conventional compared with organic production system, meat type (breast, and leg, with or without skin) and supermarket of origin on fat and fatty acid concentrations in meat were determined by analysis of variance using a fixed effect general linear model (Mintab 16.0; Minitab Inc., State College, PA, USA). Tukey's pairwise multiple comparison test was used to identify which treatments were significantly different from each other when the significance was $\mathrm{P}<0.05$.

\section{Results}

Table 2 reports the fat and fatty acid concentrations in the cooked chicken meat. Overall, total fat content was higher $(P<0.01)$ in conventionally produced meat than organic, with leg meat containing higher $(P<0.001)$ concentrations of fat than breast meat. The inclusion of skin with breast and leg meat also increased $(P<0.05)$ fat content of these meat types by factors of 3.0 and 1.8 respectively. For fat content, there was a production system $\mathrm{x}$ supermarket interaction $(P<0.001)$, as a result of Supermarket 3 having more than double the fat content in its conventional meat than organic (8.7 vs. $4.1 \mathrm{~g} / 100 \mathrm{~g}, P<0.05)$, whereas differences for the other supermarkets were much smaller and non-significant $(P>0.05)$. 
Overall, the concentrations of six fatty acids were significantly affected by production system. Four (cis-9 16:1; cis-9 18:1; 18:3 n-3; 20:3 n-6) were higher $(P<0.05)$ in conventionally produced meat than organic meat whereas two $(20: 4$ n-6 and DHA) were lower $(P<0.001)$. These results led to higher concentrations of total cis-monounsaturated fatty acids (MUFA) $(P<0.001)$ and total n-3 PUFA $(P<0.01)$ in conventional meat and higher concentrations of EPA+DHA $(P<0.01)$ and EPA + docosapentaenoic acid (DPA, 22:5 n-3) + DHA $(P<0.05)$ in organic meat. The concentrations of EPA, DPA and DHA were however, highly influenced by the production system $\mathrm{x}$ supermarket interaction $(P<0.001)$. Detailed examination showed that only in Supermarket 1 were these fatty acids significantly $(P<0.05)$ higher in organic than conventional meat. Moreover, the differences for Supermarket 1 were very large with concentrations for EPA, DPA and DHA of 7.82, 18.9 and 6.73 $\mathrm{mg} / 100 \mathrm{~g}$ respectively in conventional meat and 24.6, 35.6 and $72.4 \mathrm{mg} / 100 \mathrm{~g}$ in organic meat. Other production system x supermarket interactions reflected generally less marked disagreements between supermarkets on the relative values of conventional vs. organic meat. Meat type had a major influence on fatty acid concentration with values largely reflecting the effects seen for fat content of breast vs. leg meat and the inclusion or not of skin.

Table 3 reports fatty acid profile (g/100 g total fatty acids) of the lipid in the cooked chicken meat and shows that cis-MUFA were most abundant. Ten fatty acids (14:0, 16:0, 16:1 cis-9, 18:0, 18:1 cis-9, 18:2 n-6, 18:3 n-3, 20:0, 24:4 n-6, DHA) were affected $(P<0.05)$ by production system with total saturated fatty acids (SFA) being of lower concentration in fat from conventional than organic meat $(P<0.001)$ although the production system $\mathrm{x}$ supermarket interaction indicated that was only the case for Supermarkets 2 and 3. Overall, lipid from conventional meat was higher in cis-MUFA $(P<0.001)$, predominantly 18:1 cis-9, and 18:3 n-3 (both $P<0.001$ ), whilst lipid from organic meat was richer in total n-6 polyunsaturated fatty acids (PUFA), EPA+DHA and EPA+DHA+DPA (all $P<0.001)$. However significant production system $\mathrm{x}$ supermarket interactions $(P<0.001)$ had high 
influence on the interpretation of EPA and DHA since significantly higher values were only seen in the organic meat fatty acid profile for Supermarket 1. Supermarket 1 differences in DHA were most marked, with values of 0.161 and $1.43 \mathrm{~g} / 100 \mathrm{~g}$ total fatty acids for conventional and organic respectively $(\mathrm{P}<0.001)$. Overall, the higher SFA and mainly $\mathrm{n}-6$ PUFA concentrations in fatty acid profile from organic meat were balanced by higher cis-MUFA concentrations in lipid from the conventional meat.

\section{Discussion}

With the large increase in consumption of chicken meat over the last 60 years, and more recently a rise in organic chicken production, information on its nutritional composition and any effect of production system is a priority. There are however few published data on the total fat and fatty acid contents of cooked broiler meat and similarly little comparative information on the effect of organic versus conventional production (Minihane et al., 2008). The total fat contents of the meat in the current study are in good agreement with those reported by Givens et al. (2011) for meat from conventional and free range birds with the wide range of values (1.3 to $13.8 \mathrm{~g} / 100 \mathrm{~g}$ ) being primarily a function of meat source (breast, leg) and skin inclusion. The variation in fat content is not reflected in the declared fat contents of whole birds which is therefore of very limited nutritional value to the consumer. Overall, whilst the total fat concentration in the conventional meat was significantly $(P<0.01)$ greater than in the organic meat with mean fat contents across all meat types of 7.4 and $6.1 \mathrm{~g} / 100 \mathrm{~g}$ respectively, this was influenced by Supermarket 3 which had the highest $(8.7$ $\mathrm{g} / 100 \mathrm{~g})$ and lowest $(4.1 \mathrm{~g} / 100 \mathrm{~g})$ fat content of conventional and organic meat respectively. Husak, Sebranek and Bregendahl (2008) reported lower fat contents of organic than conventional US retail meat possibly due, in part at least, to greater locomotive and other outdoor activity by the organic birds than their housed counterparts (Andrews, Omed and Phillips,1997; Branciari et al., 2009). 
Givens et al. (2011) did not see a significant difference in total fat content of retail meat from free range and conventional broilers, suggesting that other factors such bird genotype may also influence fat deposition.

The review of Minihane et al. (2008) identified only eight truly organic vs. conventional study comparisons for fatty acids in chicken meat with most studies reporting only fatty acid profile (Castellini, Mugnai and Dal Bosco, 2002) or fatty acids in phospholipid and neutral lipids fractions (Jahan and Paterson, 2007) and not in whole edible cooked meat. Fat from organic meat in the present study contained a higher concentration of SFA (mainly 16:0), n-6 PUFA (mainly 18:2) and long chain n-3 PUFA (notably EPA and DHA) but a lower concentration of cis-MUFA than meat from conventionally produced birds. However there were interactions with supermarket for all these fatty acids. This was particularly notable for DHA where the higher value for Supermarket 1 outweighed non-significant differences for the other two supermarkets. This suggests that the bird diet used in the two production systems by the supplier of Supermarket 1 were substantially different in EPA and DHA content. More long chain n-3 PUFA in the profile of organic meat was reported by Castellini et al. (2002) although their study used the same diets for both the organic (free range) and intensively produced birds, with higher cis-PUFA and DHA concentrations in lipids from organic meat being attributed to differences in grass ingestion by the organic birds, as found in another study (Ponte et al., 2008). Husak et al. (2008) also reported significantly more cisPUFA and less cis-MUFA in lipid of meat from organic than conventional retail chickens. Grass ingestion seems unlikely to explain the differences seen for Supermarket 1 in the present study as 18:3 n-3 was present at lower $(\mathrm{P}<0.001)$ concentrations in the organic meat profile, and this fatty acid is the predominant fatty acid in grass lipid (Hawke, 1973). 
213 The reason for the greater concentrations of DHA in the lipid from the Supermarket 1 organic meat 214 is unclear. It is known however, that EU rules governing dietary ingredients permitted for organic 215 birds (European Commission, 2008) often make it difficult to achieve sufficiently high dietary 216 protein quality, so to overcome this, diets for organic meat poultry have in recent times often 217 included small but permitted amounts of fish meal (E. Snow, Personal Communication). This would 218 seem to be the most likely explanation although dietary information for the birds analysed was not 219 known. It has also been shown that earthworms, which could be available to organically-reared birds, contain EPA, DPA and DHA although EPA was the most abundant (Shibahara, Yamamoto,

An objective of the present study was to re-assess the contribution of poultry meat to intake of EPA and DHA by UK adults and whether this differs between meat from organic and conventional production systems. Earlier estimates of EPA and DHA intake by Givens and Gibbs (2006) used average concentrations of EPA, DHA and DPA in poultry meat of $15.0,35.0$ and $15.0 \mathrm{mg} / 100 \mathrm{~g}$ respectively. These values were based on research papers which may not have reflected contemporary commercial broiler production although they match reasonably the values for conventional leg meat with skin in the present study. Overall, the present results suggest that a 250 g portion of conventional and organic chicken skinless breast meat cooked in a roasting bag under the conditions used in this study would supply 58 and $84 \mathrm{mg}$ EPA + DHA respectively, however the apparent advantage of the organic meat was due only to very much higher DHA concentrations ( 10 times higher than conventional) in all meat types from Supermarket 1. For example, mean values of 4.0 and $57.5 \mathrm{mg}$ DHA/100g were measured in conventional and organic skinless breast meat respectively. This shows that the organic label is not a guarantee of higher concentrations of long chain n-3 PUFA. Like the findings of Wang et al. (2009) and Givens et al. (2011), the present 
DHA. The factors which influence the deposition of DPA in meat are unclear, but like DHA, DPA was only significantly higher in organic meat from Supermarket 1 suggesting a link between the deposition of both fatty acids.

The role of dietary DPA is unclear although some recent studies suggest it may be beneficial to human health. Howe, Buckley and Meyer, (2007) reported that the few human intervention trials that have been performed with DPA-rich supplements all found that DPA was equally, if not more, beneficial in reducing the risk of cardiovascular diseases than EPA or DHA. Sun et al. (2008) also found higher plasma EPA and DPA (but not DHA) concentrations were associated with a lower risk of nonfatal myocardial infarction. Given the trends in chicken meat consumption, further clarification of the health effects of DPA relative to EPA and DHA is required.

The present study has weaknesses. The sample number was not large and it was also limited to supermarkets in the Reading area and only one cooking method was used. Despite these issues, to our knowledge this is the only study of its type. Future studies covering a larger geographical area and the effect of different cooking methods/temperatures would therefore be desirable.

\section{Conclusions}

Meat from retail chickens in the declared weight range 1.4 to $1.6 \mathrm{~kg}$ is likely to have a fat content of approximately $1.7,5.2,7.7$ and $12.9 \mathrm{~g} / 100 \mathrm{~g}$ cooked weight in skinless breast, breast with skin, skinless leg and leg meat with skin respectively, with meat from organic production being of slightly lower fat content. Chicken meat was a rich source of cis-MUFA although the organic meat contained less than conventional. A lower total n-3 PUFA concentration in the organic meat was due to lower 18:3 n-3 although in contrast, the organic meat contained more EPA and DHA than 
263 conventional meat. The higher EPA and DHA in the organic meat was however, the result of a large 264 difference for only one supermarket and means that poultry meat labelled as organic is not a 265 guarantee of higher long chain n-3 PUFA. Overall, there was little evidence that meat from organic 266 chickens had fatty acid profiles which would be classified as healthier than that from conventionally 267 produced birds and the marked rearing system x supermarket interactions suggest different lipids 268 have been used in diets for organic birds supplied to different supermarkets. The interpretation of 269 the findings is clearly limited by the study being relatively small, although to our knowledge this is 270 the only study of its type. Further larger scale studies covering a larger geographical area and 271 different cooking methods/temperatures are therefore needed to extend the current work.

\section{Acknowledgments}

275 Financial support for the research was provided by the University of Reading. We wish to 276 acknowledge the help of Dr Darren Juniper in obtaining the birds and the preparation of the meat 277 homogenates. All authors contributed to the design of the study and manuscript, and approved the 278 final version of the manuscript. The authors declare no conflict of interest. 


\section{References}

Andrews, S. M., Omed, H. M., \& Phillips, C. J. (1997). The effect of a single or repeated period of high stocking density on the behaviour and response to stimuli in broiler chickens. Poultry Science, 76, 1655-1660.

Bates, B., Lennox, A., Prentice, A., Bates, C., Page, P., Nicholson, S., \& Swan, G. (2014). National Diet and Nutrition Survey, Results from Years 1-4 (combined) of the Rolling Programme (2008/2009-2011/12). A survey carried out on behalf of Public Health England and the Food Standards Agency.

Branciari, R., Mugnai, C., Mammoli, R., Miraglia, D., Ranucci, D., Dal Bosco, A., \& Castellini, C. (2009). Effect of genotype and rearing system on chicken behavior and muscle fiber characteristics. Journal of Animal Science, 87, 4109-4117.

Brown, R. H., \& Mueller-Harvey, I. (1999). Evaluation of the novel Soxflo technique for rapid extraction of crude fat in foods and animal foods. Journal of AOAC International, 82, 13691374.

Castellini, C., Mugnai, C., \& Dal Bosco, A. (2002). Effect of organic production system on broiler carcass and meat quality. Meat Science, 60, 219-225.

Dangour, A.. D., Dodhia, S. K., Hayter, A., Alle,n E., Lock, K., \& Uauy, R. (2009). Nutritional quality of organic foods: a systematic review. American Journal of Clinical Nutrition, 90, $680-685$.

European Commission (2008). EU Organic Commission Regulation (EC) No 889/2008. Official Journal of the European Union, L 250/1 p. 12 -20.

Givens, D. I., \& Gibbs, R. A. (2006). Very long chain n-3 polyunsaturated fatty acids in the food chain in the UK and the potential of animal-derived foods to increase intake. Nutrition Bulletin 31, 104-110. 
Givens, D. I., \& Gibbs, R. A. (2008). Current intakes of EPA and DHA in European populations and the potential of animal-derived foods to increase them. Proceedings of the Nutrition Society, 67, 273-280.

Givens, D. I., Gibbs, R. A., Rymer, C., \& Brown, R. H. (2011). Effect of intensive vs. free range production on the fat and fatty acid composition of whole birds and edible portions of UK retail chickens. Food Chemistry, 127, 1549-1554.

Hawke, J. C. (1973). Lipids. In G. W. Butler, \& R. W. Bailey (Eds.) Chemistry and Biochemistry of Herbage, Volume 1. (pp. 213-263). London, UK: Academic Press.

Howe, P., Buckley, J., \& Meyer, B. (2007). Long-chain omega-3 fatty acids in red meat. Nutrition \& Dietetics, 64 (Suppl 4), S135-S13.

Husak, R. L., Sebranek, J. G., \& Bregendahl, K. (2008). A survey of commercially available broilers marketed as organic, free-range, and conventional broilers for cooked meat yields, meat composition, and relative value. Poultry Science, 87, 2367-2376.

Jahan, K., \& Paterson, A. (2007). Lipid composition of retailed organic, free-range and conventional chicken breasts. International Journal of Food Science and Technology, 42, 251-262.

MAFF (2001). Household Consumption of Selected Foods from 1942 onwards. The National Food Survey. URL http://statistics.defra.gov.uk/esg/publications/nfs/datasets/allfood.xls Accessed 05.08.14.

Minihane, A.-M., Givens, D. I., \& Gibbs, R. A. (2008). The health benefits of $n-3$ fatty acids and their concentrations in organic and conventional animal-derived foods. In D. I. Givens, S. J. Baxter, A.-M. Minihane, \& E. J. Shaw (Eds.), Health Benefits of Organic Food: Effects of the Environment (pp. 19-49). Wallingford, UK: CABI Publishing Ltd.

Ponte, P. I. P., Alves, S. P., Bessa, R. J. B., Ferreira, L. M. A,, Gama, L.T., Bras, J. L.A., Fontes, C. M. G. A., \& Prates, J. A. M. (2008). Influence of pasture intake on the fatty acid composition, 
and cholesterol, tocopherols, and tocotrienols content in meat from free-range broilers. Poultry Science, 87, 80-88.

SACN/COT (2004) Scientific Advisory Committee on Nutrition (SACN) and Committee on Toxicity (COT), Advice on Fish Consumption: Benefits and Risks. Norwich: TSO, 204pp.

Shibahara, A., Yamamoto, K., Kinoshita, A., \& Miyatani, S. (2003). Fatty acids of the total lipids from earthworms. Journal of Rehabilitation and Health Sciences, 1, 23-28.

Soil Association (2010). Organic Market Report 2010. URL http://www.soilassociation.org/LinkClick.aspx?fileticket=bTXno01MTtM=\&tabid=116 Accessed 15.10.11.

Sukhija P. S., \& Palmquist, D. L. (1988). Rapid method for determination of total fatty acid content and composition of feedstuffs and faeces. Journal of Agricultural and Food Chemistry, 36, 1202-1206.

Sun, Q., Ma, J., Campos, H., Rexrode, K. M., Albert, C. M., Mozaffarian, D., \& Hu, F.B. (2008). Blood concentrations of individual long-chain n-3 fatty acids and risk of nonfatal myocardial infarction. American Journal of Clinical Nutrition, 88, 216-223.

Wang, Y., Lehane, C., Ghebremeskel, K., \& Crawford, M. A. (2009). Modern organic and broiler chickens sold for human consumption provide more energy from fat than protein. Public Health Nutrition, 13, 400-408. 
349 Table 1. Details of purchased chickens

\begin{tabular}{|c|c|c|c|c|c|}
\hline Supermarket & $\begin{array}{l}\text { Bird } \\
\text { number }\end{array}$ & $\begin{array}{l}\text { Production } \\
\text { system }^{1}\end{array}$ & $\begin{array}{l}\text { Declared } \\
\text { fat content } \\
(\mathrm{g} / 100 \mathrm{~g})^{2}\end{array}$ & $\begin{array}{l}\text { Declared } \\
\text { weight } \\
(\mathrm{kg})\end{array}$ & $\begin{array}{l}\text { Cost } \\
(£ / \mathrm{kg})\end{array}$ \\
\hline \multirow[t]{4}{*}{1} & 1 & $\mathrm{C}$ & 9.5 & 1.45 & 2.76 \\
\hline & 2 & $\mathrm{C}$ & 9.5 & 1.45 & 2.76 \\
\hline & 3 & $\mathrm{O}$ & 8.6 & 1.434 & 5.99 \\
\hline & 4 & $\mathrm{O}$ & 8.6 & 1.46 & 5.99 \\
\hline \multirow[t]{4}{*}{2} & 5 & $\mathrm{C}$ & 4.8 & 1.58 & 2.67 \\
\hline & 6 & $\mathrm{C}$ & 4.8 & 1.5 & 2.67 \\
\hline & 7 & $\mathrm{O}$ & 5.3 & 1.448 & 3.98 \\
\hline & 8 & $\mathrm{O}$ & 6.6 & 1.52 & 6.06 \\
\hline \multirow[t]{4}{*}{3} & 9 & $\mathrm{C}$ & $\mathrm{ND}^{3}$ & 1.6 & 3.09 \\
\hline & 10 & $\mathrm{C}$ & ND & 1.45 & 3.09 \\
\hline & 11 & $\mathrm{O}$ & 12.5 & 1.595 & 5.48 \\
\hline & 12 & $\mathrm{O}$ & 12.5 & 1.5 & 5.48 \\
\hline
\end{tabular}

$350{ }^{\mathrm{I}} \mathrm{C}$, conventional; $\mathrm{O}$, organic; ${ }^{2}$ on label, assumed to be of whole carcass; ${ }^{3} \mathrm{ND}$, not declared 
Table 2. Effect of conventional (C) or organic (O) production system (PS), meat type (MT) and supermarket (S) on fat and fatty acid content of cooked chicken meat (values are least square means; $\mathrm{mg} / 100 \mathrm{~g}$ cooked tissue).

\begin{tabular}{|c|c|c|c|c|c|c|c|c|c|c|c|c|c|c|}
\hline & \multicolumn{2}{|c|}{ Breast meat, no skin } & \multicolumn{2}{|c|}{ Breast meat with skin } & \multicolumn{2}{|c|}{ Leg meat, no skin } & \multicolumn{2}{|c|}{ Leg meat with skin } & \multicolumn{6}{|c|}{ Overall effects: } \\
\hline & $\mathrm{C}$ & $\mathrm{O}$ & $\mathrm{C}$ & $\mathrm{O}$ & $\mathrm{C}$ & $\mathrm{O}$ & $\mathrm{C}$ & $\mathrm{O}$ & $\mathrm{SED}^{+}$ & PS & MT & $S$ & $\begin{array}{l}\text { PS x } \\
\text { MT } \\
\end{array}$ & $\begin{array}{c}\text { PS x } \\
\text { S }\end{array}$ \\
\hline $\begin{array}{l}\text { Total fat }(\mathrm{g} / 100 \mathrm{~g} \\
\text { tissue) }\end{array}$ & $2.1^{\mathrm{de}}$ & $1.3^{\mathrm{e}}$ & $5.6^{b c}$ & $4.9^{\text {cd }}$ & $8.0^{b}$ & $6.2^{\mathrm{bc}}$ & $13.8^{\mathrm{a}}$ & $11.9^{\mathrm{a}}$ & 0.88 & $* *$ & $* * *$ & $*$ & $\mathrm{NS}$ & $* * *$ \\
\hline $14: 0$ & $10.4^{\mathrm{c}}$ & $9.6^{\mathrm{c}}$ & $25.9^{\mathrm{b}}$ & $23.5^{\mathrm{bc}}$ & $33.8^{\mathrm{b}}$ & $31.9^{\mathrm{b}}$ & $55.6^{\mathrm{a}}$ & $59.7^{\mathrm{a}}$ & 4.65 & NS & $* * *$ & NS & NS & $* * *$ \\
\hline 16:0 & $522^{\mathrm{c}}$ & $470^{c}$ & $1201^{\mathrm{b}}$ & $1070^{\mathrm{bc}}$ & $1567^{\mathrm{b}}$ & $1373^{b}$ & $2541^{\mathrm{a}}$ & $2478^{\mathrm{a}}$ & 177.3 & NS & $* * *$ & $*$ & NS & $* * *$ \\
\hline $16: 1$ cis-9 & $86.3^{\mathrm{de}}$ & $63.4^{\mathrm{e}}$ & $246^{\mathrm{cd}}$ & $176^{\text {cde }}$ & $342^{\mathrm{bc}}$ & $257^{\mathrm{c}}$ & $552^{\mathrm{a}}$ & $486^{\mathrm{ab}}$ & 51.7 & $*$ & $* * *$ & $* * *$ & NS & $* * *$ \\
\hline 18:0 & $202^{\mathrm{de}}$ & $201^{\mathrm{e}}$ & $350^{\mathrm{cd}}$ & $363^{c}$ & $498^{\mathrm{bc}}$ & $520^{\mathrm{b}}$ & $716^{\mathrm{a}}$ & $790^{\mathrm{a}}$ & 46.3 & NS & $* * *$ & NS & NS & $* *$ \\
\hline 18:1 cis-9 & $814^{\mathrm{e}}$ & $554^{\mathrm{e}}$ & $2071^{\mathrm{cd}}$ & $1412^{\mathrm{de}}$ & $2751^{\mathrm{bc}}$ & $1897^{\mathrm{cd}}$ & $4518^{\mathrm{a}}$ & $3535^{\mathrm{b}}$ & 304.2 & $* * *$ & $* * *$ & $* *$ & NS & $* * *$ \\
\hline $18: 2$ cis-9,12(n-6) & $352^{\mathrm{c}}$ & $399^{\mathrm{c}}$ & $815^{\mathrm{bc}}$ & $910^{\mathrm{bc}}$ & $1267^{\mathrm{b}}$ & $1307^{\mathrm{b}}$ & $1975^{\mathrm{a}}$ & $2415^{\mathrm{a}}$ & 197.9 & NS & $* * *$ & $* *$ & NS & $* *$ \\
\hline $18: 3$ cis-6,9,12 (n-6) & $2.4^{\mathrm{c}}$ & $2.2^{\mathrm{c}}$ & $5.0^{\mathrm{bc}}$ & $4.4^{\mathrm{bc}}$ & $8.0^{\mathrm{b}}$ & $7.1^{\mathrm{b}}$ & $12.1^{\mathrm{a}}$ & $12.5^{\mathrm{a}}$ & 1.22 & NS & $* * *$ & NS & NS & $* *$ \\
\hline $18: 3$ cis- $9,12,15(\mathrm{n}-3)$ & $46.6^{\mathrm{cd}}$ & $30.0^{\mathrm{d}}$ & $123^{\mathrm{c}}$ & $76.8^{\mathrm{cd}}$ & $207^{\mathrm{b}}$ & $122^{\mathrm{c}}$ & $344^{\mathrm{a}}$ & $230^{\mathrm{b}}$ & 24.3 & $* * *$ & $* * *$ & NS & * & $*$ \\
\hline $20: 0$ & $1.4^{\mathrm{b}}$ & $1.8^{\mathrm{b}}$ & $1.8^{\mathrm{b}}$ & $2.8^{\mathrm{b}}$ & $3.1^{\mathrm{b}}$ & $3.8^{\mathrm{b}}$ & $5.7^{\mathrm{ab}}$ & $10.0^{\mathrm{a}}$ & 1.73 & NS & $* * *$ & NS & NS & NS \\
\hline $20: 1$ cis-8 & $0.70^{\mathrm{b}}$ & $0.61^{\mathrm{b}}$ & $2.4^{\mathrm{ab}}$ & $1.9^{\mathrm{ab}}$ & $2.2^{\mathrm{ab}}$ & $2.4^{\mathrm{ab}}$ & $3.0^{\mathrm{ab}}$ & $4.4^{\mathrm{a}}$ & 0.866 & NS & $* * *$ & $*$ & NS & NS \\
\hline $20: 1$ cis-11 & 2.3 & 1.4 & 5.6 & 5.4 & 3.4 & 8.0 & 4.7 & 11.5 & 4.42 & NS & NS & NS & NS & NS \\
\hline 20:2 cis-11,14 (n-6) & $11.0^{\mathrm{bc}}$ & $6.9^{\mathrm{c}}$ & $14.6^{\mathrm{b}}$ & $13.2^{\mathrm{bc}}$ & $16.9^{\mathrm{ab}}$ & $17.0^{\mathrm{ab}}$ & $21.2^{\mathrm{a}}$ & $21.9^{\mathrm{a}}$ & 1.97 & NS & $* * *$ & $* *$ & NS & NS \\
\hline $20: 3$ cis-8,11,14 (n-6) & $14.9^{\mathrm{bc}}$ & $11.9^{\mathrm{c}}$ & $15.7^{\mathrm{abc}}$ & $14.0^{\mathrm{bc}}$ & $19.9^{\mathrm{ab}}$ & $16.6^{\mathrm{abc}}$ & $21.5^{\mathrm{a}}$ & $19.8^{\mathrm{ab}}$ & 1.99 & $*$ & $* * *$ & $*$ & NS & $* * *$ \\
\hline $20: 4$ cis-5,8,11,14 (n-6) & $49.8^{c}$ & $62.7^{\mathrm{bc}}$ & $49.1^{\mathrm{c}}$ & $70.8^{\mathrm{bc}}$ & $86.8^{\mathrm{ab}}$ & $106.4^{\mathrm{a}}$ & $87.3^{\mathrm{ab}}$ & $105.6^{\mathrm{a}}$ & 9.34 & $* * *$ & $* * *$ & $*$ & NS & $*$ \\
\hline 22:0 & $2.4^{\mathrm{bcd}}$ & $2.1^{\mathrm{cd}}$ & $3.4^{\mathrm{abcd}}$ & $1.7^{\mathrm{d}}$ & $5.4^{\mathrm{abc}}$ & $4.9^{\mathrm{abcd}}$ & $5.5^{\mathrm{ab}}$ & $5.9^{\mathrm{a}}$ & 1.03 & NS & $* * *$ & NS & NS & NS \\
\hline $22: 1$ cis-13 & 2.3 & 1.1 & 2.5 & 1.0 & 1.7 & 3.6 & 4.7 & 6.2 & 1.65 & NS & $* *$ & $*$ & NS & NS \\
\hline $22: 2$ cis-13,16 (n-6) & 0.73 & 0.89 & 0.91 & 1.3 & 2.0 & 2.2 & 1.8 & 1.1 & 0.911 & NS & NS & NS & NS & NS \\
\hline $\begin{array}{l}22: 4 c i s-7,10,13,16(\mathrm{n}- \\
6)\end{array}$ & $11.8^{\mathrm{b}}$ & $9.7^{\mathrm{b}}$ & $11.2^{\mathrm{b}}$ & $12.5^{\mathrm{b}}$ & $19.2^{\mathrm{a}}$ & $18.9^{\mathrm{a}}$ & $18.9^{\mathrm{a}}$ & $19.3^{\mathrm{a}}$ & 1.87 & NS & $* * *$ & $* * *$ & NS & $* *$ \\
\hline EPA $(n-3)^{1}$ & 9.5 & 8.5 & 9.0 & 10.6 & 11.4 & 13.9 & 12.1 & 18.9 & 4.62 & NS & NS & $* *$ & NS & $* * *$ \\
\hline $\operatorname{DPA}(n-3)^{2}$ & $19.0^{\mathrm{ab}}$ & $16.3^{\mathrm{b}}$ & $17.1^{\mathrm{b}}$ & $20.4^{\mathrm{ab}}$ & $28.7^{\mathrm{ab}}$ & $30.3^{\mathrm{a}}$ & $28.6^{\mathrm{ab}}$ & $31.8^{\mathrm{a}}$ & 4.01 & NS & $* * *$ & NS & NS & $* * *$ \\
\hline DHA $(n-3)^{3}$ & $13.7^{\mathrm{ab}}$ & $25.2^{\mathrm{ab}}$ & $12.2^{\mathrm{b}}$ & $24.5^{\mathrm{ab}}$ & $14.7^{\mathrm{ab}}$ & $36.4^{\mathrm{ab}}$ & $14.4^{\mathrm{ab}}$ & $37.5^{\mathrm{a}}$ & 7.58 & $* * *$ & NS & $* * *$ & NS & $* * *$ \\
\hline 24:0 & 1.9 & 1.8 & 2.6 & 1.8 & 3.0 & 1.9 & 5.7 & 2.1 & 1.35 & NS & NS & NS & NS & NS \\
\hline $24: 1$ cis-15 & 1.3 & 0.61 & 1.5 & 1.1 & 0.92 & 1.7 & 1.3 & 1.6 & 0.361 & NS & NS & $* *$ & $*$ & $* *$ \\
\hline
\end{tabular}


Table 2. Continued

\begin{tabular}{|c|c|c|c|c|c|c|c|c|c|c|c|c|c|c|}
\hline & \multicolumn{2}{|c|}{ Breast meat, no skin } & \multicolumn{2}{|c|}{ Breast meat with skin } & \multicolumn{2}{|c|}{ Leg meat, no skin } & \multicolumn{2}{|c|}{ Leg meat with skin } & \multicolumn{6}{|c|}{ Overall effects: } \\
\hline & $\mathrm{C}$ & $\mathrm{O}$ & $\mathrm{C}$ & $\mathrm{O}$ & $\mathrm{C}$ & $\mathrm{O}$ & $\mathrm{C}$ & $\mathrm{O}$ & SED & PS & MT & $\mathrm{S}$ & $\begin{array}{c}\text { PS x } \\
\text { MT }\end{array}$ & $\begin{array}{c}\text { PS x } \\
\text { S }\end{array}$ \\
\hline Total SFA & $738^{\text {cd }}$ & $684^{d}$ & $1582^{b}$ & $1461^{b c}$ & $2108^{b}$ & $1933^{b}$ & $3323^{\mathrm{a}}$ & $3343^{\mathrm{a}}$ & 222.3 & NS & $* * *$ & NS & NS & $* * *$ \\
\hline Total cis-MUFA ${ }^{4}$ & $990^{\mathrm{e}}$ & $677^{\mathrm{e}}$ & $2501^{\mathrm{cd}}$ & $1722^{\mathrm{de}}$ & $3324^{\mathrm{bc}}$ & $2338^{\mathrm{cd}}$ & $5439^{\mathrm{a}}$ & $4325^{\mathrm{ab}}$ & 372.4 & $* * *$ & $* * *$ & $* *$ & NS & $* * *$ \\
\hline Total cis-PUFA ${ }^{4}$ & $533^{\mathrm{c}}$ & $574^{\mathrm{c}}$ & $1074^{\mathrm{bc}}$ & $1159^{b c}$ & $1683^{b}$ & $1679^{b}$ & $2538^{\mathrm{a}}$ & $2915^{\mathrm{a}}$ & 231.8 & NS & $* * *$ & $* *$ & NS & $* *$ \\
\hline Total n-6 PUFA & $443^{c}$ & $493^{c}$ & $911^{\mathrm{bc}}$ & $1026^{\mathrm{bc}}$ & $1420^{\mathrm{b}}$ & $1475^{\mathrm{b}}$ & $2138^{\mathrm{a}}$ & $2595^{\mathrm{a}}$ & 204.7 & NS & $* * *$ & $* *$ & NS & $* *$ \\
\hline Total n-3 PUFA & $88.9^{\mathrm{e}}$ & $79.9^{\mathrm{e}}$ & $162^{\text {cde }}$ & $132^{\mathrm{de}}$ & $262^{b c}$ & $203^{\mathrm{cd}}$ & $399^{\mathrm{a}}$ & $318^{\mathrm{ab}}$ & 31.4 & $* *$ & $* * *$ & $*$ & NS & $* * *$ \\
\hline $\mathrm{EPA}+\mathrm{DHA}$ & 23.2 & 33.6 & 21.2 & 35.0 & 26.1 & 50.3 & 26.5 & 56.4 & 11.97 & $* *$ & NS & $* * *$ & NS & $* * *$ \\
\hline $\mathrm{EPA}+\mathrm{DPA}+\mathrm{DHA}$ & $42.1^{\mathrm{ab}}$ & $49.9^{\mathrm{ab}}$ & $38.3^{\mathrm{b}}$ & $55.4^{\mathrm{ab}}$ & $54.8^{\mathrm{ab}}$ & $80.6^{\mathrm{ab}}$ & $55.2^{\mathrm{ab}}$ & $88.2^{\mathrm{a}}$ & 15.37 & $*$ & $*$ & $* * *$ & NS & $* * *$ \\
\hline
\end{tabular}

a,b,c,d,e Means within a row with no superscripts or those with a common superscript are not significantly different $(P<0.05)$

'Standard error of the difference from Tukey's pairwise comparison

$* P<0.05, * * P<0.01, * * * P<0.001$

${ }^{1}$ EPA, 5,8,11,14,17-ecosapentaenoic acid (20:5 n-3)

${ }^{2}$ DPA, 7,10,13,16,19-docosapentaenoic acid (22:5n-3)

${ }^{3}$ DHA, 4,7,10,13,16,19-docosahexaenoic acid (22:6 n-3)

${ }^{4}$ SFA, saturated fatty acids

${ }^{5}$ MUFA, monounsaturated fatty acids

${ }^{6}$ PUFA, polyunsaturated fatty acids 
Table 3. Effect of conventional (C) or organic (O) production system (PS), meat type (MT) and supermarket (S) on fatty acid profile of cooked chicken meat (values are least square means, $\mathrm{g} / 100 \mathrm{~g}$ fatty acids).

\begin{tabular}{|c|c|c|c|c|c|c|c|c|c|c|c|c|c|c|}
\hline & \multicolumn{2}{|c|}{$\begin{array}{l}\text { Breast meat, no } \\
\text { skin }\end{array}$} & \multicolumn{2}{|c|}{ Breast meat with skin } & \multicolumn{2}{|c|}{ Leg meat, no skin } & \multicolumn{2}{|c|}{ Leg meat with skin } & \multicolumn{6}{|c|}{ Overall effects: } \\
\hline & $\mathrm{C}$ & $\mathrm{O}$ & $\mathrm{C}$ & $\mathrm{O}$ & $\mathrm{C}$ & $\mathrm{O}$ & $\mathrm{C}$ & $\mathrm{O}$ & $\mathrm{SED}^{+}$ & PS & MT & $S$ & $\begin{array}{l}\text { PS x } \\
\text { MT }\end{array}$ & $\begin{array}{c}\text { PS x } \\
\text { S }\end{array}$ \\
\hline $14: 0$ & $0.42^{\mathrm{c}}$ & $0.46^{\mathrm{bc}}$ & $0.48^{\mathrm{abc}}$ & $0.52^{\mathrm{ab}}$ & $0.45^{\mathrm{bc}}$ & $0.52^{\mathrm{ab}}$ & $0.47^{\mathrm{abc}}$ & $0.55^{\mathrm{a}}$ & 0.027 & $* * *$ & ** & NS & NS & $* * *$ \\
\hline 16:0 & $21.7^{\mathrm{ab}}$ & $22.5^{\mathrm{ab}}$ & $22.5^{\mathrm{ab}}$ & $23.5^{\mathrm{a}}$ & $21.2^{\mathrm{b}}$ & $22.3^{\mathrm{ab}}$ & $21.8^{\mathrm{ab}}$ & $22.9^{\mathrm{ab}}$ & 0.56 & $* *$ & $*$ & $* * *$ & NS & $* * *$ \\
\hline $16: 1$ cis -9 & $3.4^{\mathrm{bc}}$ & $2.8^{\mathrm{c}}$ & $4.4^{\mathrm{ab}}$ & $3.8^{\mathrm{abc}}$ & $4.6^{\mathrm{a}}$ & $3.9^{\mathrm{abc}}$ & $4.7^{\mathrm{a}}$ & $4.3^{\mathrm{ab}}$ & 0.35 & $* *$ & $* * *$ & $* * *$ & NS & $* * *$ \\
\hline 18:0 & $8.6^{\mathrm{ab}}$ & $10.1^{\mathrm{a}}$ & $6.9^{\mathrm{cd}}$ & $8.1^{\mathrm{bc}}$ & $6.8^{\mathrm{cd}}$ & $8.9^{\mathrm{ab}}$ & $6.2^{\mathrm{d}}$ & $7.7^{\mathrm{bc}}$ & 0.46 & $* * *$ & $* * *$ & $* * *$ & NS & $* * *$ \\
\hline $18: 1$ cis -9 & $33.2^{\mathrm{b}}$ & $25.5^{\mathrm{d}}$ & $38.0^{\mathrm{a}}$ & $30.9^{\mathrm{bc}}$ & $37.3^{\mathrm{a}}$ & $30.0^{\mathrm{c}}$ & $38.6^{\mathrm{a}}$ & $32.0^{\mathrm{bc}}$ & 0.93 & $* * *$ & $* * *$ & $* * *$ & NS & $* * *$ \\
\hline $18: 2$ cis-9,12(n-6) & $14.8^{\mathrm{e}}$ & $19.2^{\mathrm{abcd}}$ & $15.6^{\mathrm{de}}$ & $20.4^{\mathrm{abc}}$ & $17.6^{\text {bcde }}$ & $21.5^{\mathrm{ab}}$ & $17.5^{\text {cde }}$ & $22.4^{\mathrm{a}}$ & 1.24 & $* * *$ & $* *$ & $* * *$ & NS & $* * *$ \\
\hline $18: 3$ cis-6,9,12 (n-6) & 0.095 & 0.105 & 0.096 & 0.097 & 0.110 & 0.115 & 0.110 & 0.115 & 0.0122 & NS & NS & NS & NS & NS \\
\hline $18: 3$ cis-9,12,15 (n-3) & $1.8^{\mathrm{cd}}$ & $1.3^{\mathrm{d}}$ & $2.3^{\mathrm{bc}}$ & $1.7^{\mathrm{cd}}$ & $2.8^{\mathrm{ab}}$ & $1.9^{\mathrm{cd}}$ & $3.0^{\mathrm{a}}$ & $2.1^{\mathrm{c}}$ & 0.21 & $* * *$ & $* * *$ & NS & NS & $* *$ \\
\hline 20:0 & 0.058 & 0.090 & 0.043 & 0.071 & 0.042 & 0.057 & 0.053 & 0.089 & 0.0260 & $*$ & NS & NS & NS & NS \\
\hline $20: 1$ cis -8 & 0.029 & 0.028 & 0.049 & 0.044 & 0.030 & 0.036 & 0.030 & 0.037 & 0.0142 & NS & NS & $*$ & NS & NS \\
\hline $20: 1$ cis-11 & 0.099 & 0.065 & 0.142 & 0.126 & 0.042 & 0.110 & 0.043 & 0.101 & 0.0743 & NS & NS & NS & NS & NS \\
\hline 20:2 cis-11,14 (n-6) & $0.492^{\mathrm{a}}$ & $0.354^{\mathrm{ab}}$ & $0.300^{\mathrm{ab}}$ & $0.294^{\mathrm{ac}}$ & $0.240^{\mathrm{b}}$ & $0.287^{\mathrm{ab}}$ & $0.190^{\mathrm{b}}$ & $0.216^{\mathrm{b}}$ & 0.0711 & NS & $* *$ & NS & NS & NS \\
\hline $20: 3$ cis-8,11,14 (n-6) & $0.644^{\mathrm{a}}$ & $0.574^{\mathrm{a}}$ & $0.305^{\mathrm{b}}$ & $0.297^{\mathrm{b}}$ & $0.282^{\mathrm{b}}$ & $0.270^{\mathrm{b}}$ & $0.189^{b}$ & $0.181^{\mathrm{b}}$ & 0.0473 & NS & $* * *$ & NS & NS & NS \\
\hline $20: 4$ cis-5,8,11,14 (n-6) & $2.2^{\mathrm{b}}$ & $3.4^{\mathrm{a}}$ & $0.96^{\mathrm{cd}}$ & $1.6^{\mathrm{bcd}}$ & $1.2^{\mathrm{bcd}}$ & $1.9^{\mathrm{bc}}$ & $0.76^{\mathrm{d}}$ & $1.1^{\mathrm{bcd}}$ & 0.331 & $* * *$ & $* * *$ & $* *$ & NS & $* * *$ \\
\hline 22:0 & 0.089 & 0.097 & 0.069 & 0.040 & 0.077 & 0.083 & 0.048 & 0.058 & 0.0233 & NS & NS & NS & NS & NS \\
\hline 22:1 cis-13 & 0.087 & 0.047 & 0.058 & 0.027 & 0.020 & 0.053 & 0.044 & 0.052 & 0.0274 & NS & NS & NS & NS & NS \\
\hline $22: 2$ cis-13,16 (n-6) & 0.034 & 0.040 & 0.016 & 0.025 & 0.032 & 0.045 & 0.014 & 0.014 & 0.0211 & NS & NS & NS & NS & NS \\
\hline $\begin{array}{l}22: 4 \text { cis-7,10,13,16(n- } \\
\text { 6) }\end{array}$ & $0.51^{\mathrm{a}}$ & $0.52^{\mathrm{a}}$ & $0.23^{\mathrm{b}}$ & $0.29^{\mathrm{b}}$ & $0.28^{\mathrm{b}}$ & $0.35^{\mathrm{ab}}$ & $0.17^{\mathrm{b}}$ & $0.21^{\mathrm{b}}$ & 0.061 & NS & $* * *$ & $* *$ & NS & $* * *$ \\
\hline EPA $(n-3)^{1}$ & $0.397^{\mathrm{a}}$ & $0.389^{\mathrm{a}}$ & $0.165^{\mathrm{b}}$ & $0.219^{\mathrm{ab}}$ & $0.155^{\mathrm{b}}$ & $0.205^{\mathrm{b}}$ & $0.109^{b}$ & $0.150^{\mathrm{b}}$ & 0.0562 & NS & $* * *$ & $* * *$ & NS & $* * *$ \\
\hline DPA $(n-3)^{2}$ & $0.81^{\mathrm{a}}$ & $0.82^{\mathrm{a}}$ & $0.33^{\mathrm{b}}$ & $0.45^{\mathrm{b}}$ & $0.41^{\mathrm{b}}$ & $0.49^{\mathrm{b}}$ & $0.25^{\mathrm{b}}$ & $0.29^{\mathrm{b}}$ & 0.0847 & NS & $* * *$ & NS & NS & $*$ \\
\hline DHA $(n-3)^{3}$ & $0.56^{\mathrm{b}}$ & $1.2^{\mathrm{a}}$ & $0.22^{\mathrm{b}}$ & $0.52^{\mathrm{b}}$ & $0.21^{\mathrm{b}}$ & $0.55^{\mathrm{b}}$ & $0.12^{\mathrm{b}}$ & $0.31^{\mathrm{b}}$ & 0.171 & $* * *$ & $* * *$ & $* * *$ & NS & $* * *$ \\
\hline 24:0 & 0.087 & 0.089 & 0.055 & 0.039 & 0.046 & 0.034 & 0.045 & 0.020 & 0.0212 & NS & $* *$ & NS & NS & NS \\
\hline 24:1 cis-15 & $0.069^{\mathrm{a}}$ & $0.037^{\mathrm{ab}}$ & $0.031^{\mathrm{ab}}$ & $0.026^{\mathrm{ab}}$ & $0.013^{\mathrm{b}}$ & $0.029^{\mathrm{ab}}$ & $0.012^{\mathrm{b}}$ & $0.016^{\mathrm{b}}$ & 0.0153 & NS & $* *$ & $*$ & NS & $* *$ \\
\hline
\end{tabular}


Table 3. Continued

\begin{tabular}{|c|c|c|c|c|c|c|c|c|c|c|c|c|c|c|}
\hline & \multicolumn{2}{|c|}{$\begin{array}{l}\text { Breast meat, no } \\
\text { skin }\end{array}$} & \multicolumn{2}{|c|}{ Breast meat with skin } & \multicolumn{2}{|c|}{ Leg meat, no skin } & \multicolumn{2}{|c|}{ Leg meat with skin } & \multicolumn{6}{|c|}{ Overall effects: } \\
\hline & $\mathrm{C}$ & $\mathrm{O}$ & $\mathrm{C}$ & $\mathrm{O}$ & $\mathrm{C}$ & $\mathrm{O}$ & $\mathrm{C}$ & $\mathrm{O}$ & SED & PS & MT & $\mathrm{S}$ & $\begin{array}{l}\text { PS x } \\
\text { MT }\end{array}$ & $\begin{array}{c}\mathrm{PS} x \\
\text { S }\end{array}$ \\
\hline Total SFA & $31.0^{\mathrm{abc}}$ & $33.3^{\mathrm{a}}$ & $30.0^{\mathrm{bc}}$ & $32.3^{\mathrm{ab}}$ & $28.6^{\mathrm{c}}$ & $31.9^{\mathrm{ab}}$ & $28.6^{\mathrm{c}}$ & $31.4^{\mathrm{abc}}$ & 0.91 & $* * *$ & $* *$ & $* * *$ & NS & $* * *$ \\
\hline Total cis-MUFA ${ }^{5}$ & $40.3^{\mathrm{b}}$ & $31.1^{\mathrm{c}}$ & $45.8^{\mathrm{a}}$ & $37.6^{\mathrm{b}}$ & $45.0^{\mathrm{a}}$ & $36.8^{\mathrm{b}}$ & $46.5^{\mathrm{a}}$ & $39.0^{\mathrm{b}}$ & 1.20 & $* * *$ & $* * *$ & $* * *$ & NS & $* * *$ \\
\hline Total cis-PUFA ${ }^{6}$ & $22.4^{\mathrm{bc}}$ & $28.0^{\mathrm{a}}$ & $20.5^{\mathrm{c}}$ & $25.9^{\mathrm{ab}}$ & $23.4^{\mathrm{abc}}$ & $27.6^{\mathrm{a}}$ & $22.4^{\mathrm{bc}}$ & $27.1^{\mathrm{ab}}$ & 1.52 & $* * *$ & NS & $* * *$ & NS & $* * *$ \\
\hline Total n-6 PUFA & $18.8^{\mathrm{cd}}$ & $24.2^{\mathrm{ab}}$ & $17.5^{\mathrm{d}}$ & $23.0^{\mathrm{abc}}$ & $19.8^{\mathrm{bcd}}$ & $24.4^{\mathrm{a}}$ & $18.9^{\mathrm{cd}}$ & $24.2^{\mathrm{ab}}$ & 1.39 & $* * *$ & NS & $* * *$ & NS & $* * *$ \\
\hline Total n-3 PUFA & $3.6^{\mathrm{ab}}$ & $3.8^{\mathrm{a}}$ & $3.0^{\mathrm{ab}}$ & $2.9^{\mathrm{ab}}$ & $3.6^{\mathrm{ab}}$ & $3.2^{\mathrm{ab}}$ & $3.5^{\mathrm{ab}}$ & $2.8^{\mathrm{b}}$ & 0.29 & NS & $* *$ & $* * *$ & NS & $* * *$ \\
\hline $\mathrm{EPA}+\mathrm{DHA}$ & $0.96^{\mathrm{ab}}$ & $1.6^{\mathrm{a}}$ & $0.38^{b c}$ & $0.74^{\mathrm{bc}}$ & $0.36^{\mathrm{bc}}$ & $0.76^{\mathrm{bc}}$ & $0.23^{c}$ & $0.46^{\mathrm{bc}}$ & 0.210 & $* * *$ & $* * *$ & $* * *$ & NS & $* * *$ \\
\hline $\mathrm{EPA}+\mathrm{DPA}+\mathrm{DHA}$ & $1.8^{\mathrm{ab}}$ & $2.4^{\mathrm{a}}$ & $0.71^{\mathrm{cd}}$ & $1.2^{\mathrm{bcd}}$ & $0.77^{\text {cd }}$ & $1.2^{\mathrm{bc}}$ & $0.48^{\mathrm{d}}$ & $0.75^{\mathrm{cd}}$ & 0.224 & $* * *$ & $* * *$ & $* * *$ & NS & $* * *$ \\
\hline
\end{tabular}

a,b,c,d,e Means within a row with no superscripts or those with a common superscript are not significantly different $(P<0.05)$

${ }^{\dagger}$ Standard error of the difference from Tukey's pairwise comparison

$* P<0.05, * * P<0.01, * * * P<0.001$

${ }^{1}$ EPA, 5,8,11,14,17-ecosapentaenoic acid (20:5 n-3)

${ }^{2}$ DPA, 7,10,1316,19-docosapentaenoic acid (22:5 n-3)

${ }^{3}$ DHA, 4,7,10,13,16,19-docosahexaenoic acid (22:6 n-3)

${ }^{4}$ SFA, saturated fatty acids

${ }^{5}$ MUFA, monounsaturated fatty acids

${ }^{6}$ PUFA, polyunsaturated fatty acids 